\title{
ANALISIS EFEKTIVITAS IKLAN TV SIRUP MARKISA DENGAN PENDEKATAN EPIC MODEL PT. MAJUJAYA POHON PINANG PADA KONSUMEN SWALAYAN MACAM YAOHAN MERAK JINGGA MEDAN
}

\author{
Sian Yet \\ Paham Ginting
}

\begin{abstract}
Present competition of syrup business becomes tighter in terms of product quality, promotion, price and services provided. With many syrup product competing in the market, the management of company is required to be more accurate in determining the strategy used to win the competition. PT. MajuJaya PohonPinang was chosen to be the object of study because this company has applied various strategies in marketing their products and one of them is through advertisement. Therefore, it needs a follow up to find out how effective the advertisement of Pohon Pinang Markisa Syrup related to the buying decision. The purpose of this quantitive descriptive explanatory survey study conducted at PT. MajuJaya PohonPinang Macan Yaohan Supermarket Merak Jingga Medan was to find out and analyze the effectiveness of Markisa Syrup commercial advertisement viewed from EPIC (Empathy, Persuasion, Impact, and Communication) dimensions and to find out the effectiveness and to partiality analyze the EPIC dimension using the theory of marketing management related to advertisement. The population of this study was the consumers of Macan Yaohan Supermarket Merak Jingga Medan and 100 of them were selected to be respondents for this study. The data obtained were analyzed through univariate analysis with $T$ test. The result of this study showed that simultaneously the variable of Markisa Syrup TV Commercial Advertisement viewed based on the EPIC model was effective. Partially, persuasion was the most dominant variable of the effectiveness of Markisa Syrup TV Commercial Advertisement.
\end{abstract}

Keywords: Empathy, Persuation, Impact and Communication

\section{PENDAHULUAN}

Persaingan bisnis produk sirup saat ini semakin ketat baik dari segi kualitas produk, promosi, harga, maupun pelayanan yang diberikan. Dengan banyaknya bermunculan produk sirup yang bersaing di pasaran, sehingga menuntut manajemen perusahaan untuk lebih cermat dalam menentukan strategi persaingannya agar dapat memenangkan persaingan.

Sian Yet, adalah Mahasiswa Sekolah Pascasarjana Universitas Sumatera Utara Paham Ginting, adalah Dosen Fakultas Ekonomi Universitas Sumatera Utara 
Pihak manajemen perusahaan dituntut untuk dapat mendesain dan mengimplementasikan strategi pemasaran yang mampu menciptakan, mempertahankan dan meningkatkan kepuasan konsumennya, sehingga dapat menciptakan konsumen yang loyal pada merek produk yang ditawarkan oleh perusahaan.

Keberhasilan perusahaan dalam mempengaruhi konsumen untuk keputusan pembelian sangat didukung oleh upaya membangun komunikasi pada konsumen dan membangun merek yang kuat melalui strategi pemasaran, selanjutnya melakukan inovasi untuk menghasilkan varian baru pada produk perusahaan, agar mencapai keunggulan jangka waktu yang panjang.

Perusahaan memasarkan suatu produk/jasa tidak hanya memperhatikan kualitas, harga kompetitif, dan ketersediaan produk bagi konsumen sasaran, tetapi juga memerlukan komunikasi yang berkesinambungan dengan para konsumen potensial, sehingga tercipta hubungan yang erat antara konsumen dan produsen. Salah satu bentuk komunikasi yang dapat dilaksanakan adalah iklan. Jika dilaksanakan dengan baik akan membuat konsumen mengetahui produk yang dipasarkan oleh perusahaan, dengan harapan mereka tertarik dan mengambil keputusan untuk membeli produk perusahaan. Jika terjadi kesalahan dalam melakukan iklan, maka akan berdampak pada citra perusahaan dan mengakibatkan konsumen beralih pada produk lain.

Sejalan dengan pertumbuhan ekonomi, aktivitas dunia usaha di Indonesia mengalami peningkatan. Hal ini secara tidak langsung mempengaruhi perkembangan usaha dibidang periklanan. Periklanan kini telah mendapatkan pengakuan luas sebagai salah satu ujung tombak dalam aktivitas pemasaran, dan dipercaya sebagai ujung pendongkrak penjualan. Iklan juga sudah meramaikan hampir seluruh media, baik media cetak maupun elektronik.

Iklan merupakan sarana komunikasi yang dilakukan oleh perusahaan untuk memasarkan produknya. Iklan dilakukan dengan tujuan untuk membujuk, memberitahu, mempengaruhi dan menarik minat beli dari konsumen.

Pemilihan media yang tepat dapat berpengaruh terhadap efektivitas komunikasi yang disampaikan. Efektivitas iklan sangat penting bagi perencanaan periklanan dan promosi. Efektivitas dari periklanan dapat dilakukan dengan mengukur efek komunikasi yang disampaikan, melalui iklan yang tujuannya untuk mengetahui potensi pengaruh iklan tersebut pada kesadaran, pengetahuan atau preferensi dari konsumen.

Keberhasilan suatu perusahaan untuk mendapatkan kepercayaan konsumen tentunya tidak terlepas dari strategi pemasaran yang tepat dan didukung oleh produk yang berkualitas. PT. MajuJaya PohonPinang, perusahaan yang bergerak di bidang produksi sirup dari buah markisa telah menggunakan media iklan sebagai alat bantu untuk mengkomunikasikan produknya kepada konsumen. Perusahaan ini menggunakan media TV sebagai salah satu media untuk meningkatkan pengetahuan konsumen terhadap produk perusahaan.

Saat ini banyak sekali produk-produk sirup di pasaran yang hampir sama kualitasnya, sehingga menyebabkan tingkat persaingan sirup mengalami peningkatan. Hal ini didukung dengan adanya data Top Brand Index sebagai berikut: 


\begin{tabular}{|c|c|c|c|}
\hline \multirow{3}{*}{ No } & \multicolumn{3}{|c|}{$\begin{array}{c}\text { Tabel 1.] } \\
\text { Top Brand Index Produk Sirup } \\
\text { Periode Tahun 2)10-2011 }\end{array}$} \\
\hline & \multirow{2}{*}{ Merek } & \multicolumn{2}{|c|}{ Persentase } \\
\hline & & Tahun 2010 & Tahun 2011 \\
\hline 1 & Sirup $A B C$ & $49.1 \%$ & $46.8 \%$ \\
\hline 2 & SirupMaran & $29.2 \%$ & $34.0 \%$ \\
\hline 3 & Sirup Marcisa Pohon Pinang & $4.8 \%$ & $4.0 \%$ \\
\hline 4 & SirupFresh & $4.7 \%$ & $3.7 \%$ \\
\hline 5 & Sirup Bangau & $2.0 \%$ & $3.5 \%$ \\
\hline 6 & SirupKurnia & $1.8 \%$ & $1.4 \%$ \\
\hline
\end{tabular}

Iklan yang efektif akan berdampak terhadap perkembangan penjualan dan menguatkan persepsi konsumen terhadap produk perusahaan. Secara umum, kriteria yang dapat digunakan untuk mengukur efektivitas iklan menggunakan EPIC Model dari AC Nielsen. Dalam EPIC Model memisahkan empat dimensi kritis sebuah iklan yaitu Empathy, Persuasion, Impact, dan Communication untuk kemudian dianalisis guna melihat efektivitas masing-masing dimensi tersebut secara terpisah sehingga dapat diketahui pada dimensi yang manakah sebuah iklan memiliki kelemahan dalam pencapaian tujuannya, serta selanjutnya dibuat strategi baru untuk memperbaikinya.

Promosi melalui iklan televisi berkaitan erat dengan biaya yang tinggi, maka efektivitas iklan perlu diperhatikan dan dikaji dengan serius, walaupun iklan telah dipahami kegunaannya, baik oleh perorangan maupun perusahaan, sebagai sarana untuk membangun citra produk dan merek perusahaan.

Pemilihan perusahaan PT. Maju Jaya Pohon Pinang sebagai objek penelitian karena selama ini perusahaan tersebut telah melakukan berbagai strategi dalam memasarkan produknya antara lain melalui media iklan. Oleh karena itu, perlu ditindaklanjuti untuk mengetahui sejauh mana efektivitas iklan sirup Markisa Pohon Pinang yang sudah dilakukan dalam kaitannya terhadap keputusan pembelian.

Perumusan masalah dalam penelitian ini antara lain : a) apakah iklan televisi sirup markisa secara keseluruhan dilihat dari empat dimensi EPIC-Model (Empathy, Persuasion, Impact, dan Communication) sangat efektif ? b) secara parsial dimensi EPIC (Empathy, Persuasion, Impact, dan Communication) manakah yang paling efektif untuk iklan produk sirup markisa?.

Selanjutnya tujuan penelitian ini antara lain : 1). untuk mengetahui dan menganalisis efektivitas iklan produk Sirup Markisa efektif dilihat dari empat dimensi EPIC (Empathy, Persuasion, Impact, dan Communication).2) untuk mengetahui efektifitas dan menganalisis dimensi EPIC (Empathy, Persuasion, Impact, dan Communication) secara parsial. 


\section{TINJAUAN PUSTAKA}

Pemasaran merupakan salah satu dari berbagai kegiatan pokok yang harus dilakukan oleh perusahaan dalam mempertahankan kelangsungan hidupnya dan mengembangkan kemajuan usaha (bisnis) yang dijalankannya.

Menurut Kotler dan Keller (2009:5) : "inti dari pemasaran adalah mengidentifikasikan dan memenuhi kebutuhan manusia. Menurut Assauri (2004:198) : "Marketing Mix merupakan kombinasi variabel atau kegiatan yang merupakan inti dari sistem pemasaran, variabel mana dapat dikendalikan oleh perusahaan untuk mempengaruhi reaksi para pembeli atau konsumen."

Menurut Kotler dan Amstrong (2004:600) : "bauran promosi (marketing communication mix) adalah bauran pemasangan iklan, penjualan personal, promosi penjualan, hubungan masyarakat, dan alat-alat pemasaran langsung yang digunakan untuk mencapai tujuan-tujuan pemasangan iklan dan pemasaran."

Pemasangan iklan merupakan setiap bentuk presentasi dan promosi non personal yang memerlukan biaya tentang gagasan, barang atau jasa oleh sponsor yang jelas. Penjualan personal merupakan presentasi personal oleh tenaga penjualan sebuah perusahaan dengan tujuan menghasilkan transaksi penjualan dan membangun hubungan dengan konsumen. Promosi penjualan merupakan insentifinsentif jangka pendek untuk mendorong pembelian atau penjualan sebuah produk atau jasa.

Hubungan masyarakat merupakan upaya membangun hubungan baik dengan berbagai pihak perusahaan dengan sejumlah upaya memperoleh publisitas yang menguntungkan, membangun citra perusahaan yang bagus, dan menangani atau meluruskan rumor, cerita, serta event yang tidak menguntungkan.

Periklanan dipandang sebagai media yang paling lazim digunakan suatu perusahaan untuk mengarahkan komunikasi yang persuasif kepada konsumen. Iklan ditujukan untuk mempengaruhi perasaan, pengetahuan, makna, kepercayaan, sikap dan citra konsumen yang berkaitan dengan suatu produk atau merek.

Kata iklan (advertising) berasal dari bahasa Yunani yang artinya adalah 'menggiring orang pada gagasan'. Adapun pengertian iklan secara komprehensif adalah "semua bentuk aktifitas untuk menghadirkan dan mempromosikan ide, barang, atau jasa secara nonpersonal yang dibayar oleh sponsor tertentu" (Durianto, dkk 2003).

Sedangkan menurut Wells dan Moriarty (1998 dalam Sutisna, 2003), mendefinisikan iklan sebagai berikut : "Advertising is paid nonpersonal communication from an identified sponsor using mass media to persuade or influence an audience". Yang dimaksud dengan iklan ialah kegiatan yang digunakan seseorang atau sekelompok orang untuk mempengaruhi atau mengarahkan pikiran orang lain pada suatu tujuan tertentu dengan menggunakan media tertentu.

Periklanan merupakan salah satu bentuk khusus komunikasi yang biasanya digunakan oleh perusahaan untuk mengarahkan komunikasi persuasi pada konsumen sasaran dan masyarakat. Periklanan juga salah satu usaha yang dilakukan untuk menyampaikan pesan dari produk yang dihasilkan perusahaan kepada pihak konsumen, sehingga konsumen mengenal dengan baik produk yang ditawarkan perusahaan. 
Periklanan menurut Khasali (2007:18) “ meliputi suatu sistem yang terdiri dari berbagai organisasi atau lembaga yang saling berinteraksi dan menjalankan peranan yang saling berbeda dalam proses periklanan." Menurut Kotler dan Keller (2009:203) : "tujuan iklan dapat diklasifikasikan menurut tujuannya, baik untuk menginformasikan, meyakinkan, meningatkan atau memperkuat."

a. Iklan informatif bertujuan menciptakan kesadaran merek dan pengetahuan tentang produk atau fitur baru yang ada.

b. Iklan persuasif bertujuan menciptakan kesukaan, preferensi, keyakinan dan pembelian produk atau jasa.

c. Iklan pengingat bertujuan menstimulasikan pembelian berulang pada produk dan jasa.

d. Iklan penguat bertujuan meyakinkan pembeli saat ini bahwa mereka melakukan pilihan yang tepat.

Inti dari repositioning atau launching produk yang sukses adalah sebuah ide baru - konsep atau pesan yang memotivasi konsumen dan relevan dengan kebutuhan mereka. Konsep atau pesan ini dapat bekerja dalam beberapa cara berhubungan dengan konsumen, tetapi pengalaman AC Nielsen menyarankan bahwa konsep yang sukses akan :

a. Memacu respons empati membuat konsumen merasa terikat secara personal.

b. Mempersuasi konsumen untuk mengambil tindakan atau setidaknya ingin untuk menginvestigasi konsep secara lebih mendalam.

c. Memiliki dampak atau setidaknya tingkat keunikan.

d. Mengartikulasi secara jelas, setidaknya satu kelebihan produk yang relevan dan diharapkan.

Efektivitas periklanan yang berkaitan dengan penjualan dapat diketahui melalui riset tentang dampak penjualan. Sedangkan efektivitas periklanan yang berkaitan dengan pengingatan dan persuasi dapat diketahui melalui riset tentang dampak komunikasi.

Berbagai model diciptakan untuk mengukur efektivitas periklanan. Model merupakan penyederhanaan dari sesuatu yang mampu mewakili sejumlah objek atau aktivitas. Dalam mengukur efektivitas iklan, digunakan model dengan pertimbangan konsumen hidup didalam lingkungan yang kompleks, sehingga perilaku konsumen sangat kompleks.

Efektivitas iklan dapat diukur dengan menggunakan EPIC model yang dikembangkan oleh AC Nielsen, merupakan salah satu perusahaan peneliti pemasaran terkemuka di dunia. EPIC model mencakup empat dimensi kritis yaitu empati, persuasi, dampak dan komunikasi (Empathy, Persuasion, Impact and Communications), berikut dipaparkan dimensi - dimensi dalam EPIC model.

\section{Dimensi Empati}

Dimensi pembangkit respon emosional (empathy) merupakan dimensi yang menginformasikan, apakah konsumen menyukai suatu iklan dan menggambarkan bagaimana konsumen melihat hubungan antara suatu iklan dengan pribadi mereka. Dimensi empati memberikan informasi yang berharga tentang daya tarik suatu merek. 
Empati adalah kemampuan menghayati perasaan orang lain atau merasakan apa yang dirasakan orang lain. Empati dalam periklanan adalah respon afektif yang berakar dari pengertian mengenai status atau kondisi emosi orang lain.

\section{Dimensi Persuasi}

Dimensi persuasi (persuasion) merupakan dimensi menginformasikan apa yang dapat diberikan suatu iklan untuk peningkatan atau penguatan karakter suatu merek, sehingga pemasang iklan memperoleh keuntungan dari iklan tersebut, yaitu keinginan konsumen untuk membeli produk perusahaan. Persuasi (persuasion) adalah perubahan kepercayaan, sikap, dan keinginan berperilaku yang disebabkan satu komunikasi promosi. Proses persuasi ditentukan melalui tingkat keterlibatan konsumen dalam pesan promosi sebuah produk.

Untuk menetapkan tujuan, harus mengetahui status terbaru dari audiens sasaran, terutama mengenai variabel hierarki responsnya seperti kesadaran, pengetahuan, citra, sikap, dan minat untuk kemudian menentukan pada tingkat mana konsumen harus dirubah dengan kampanye periklanan (Belch, 2004, :206).

Keterlibatan adalah status motivasi yang menggerakkan serta mengarahkan proses kognitif dan perilaku konsumen pada saat mereka membuat keputusan. Berbagai anteseden dapat mempengaruhi tingkat keterlibatan konsumen dalam beberapa cara, termasuk cara konsumen merespons iklan, produk yang diiklankan, dan keputusan pembelian (Belch, 2004:154).

Memahami bahwa konsumen dapat terlibat dengan produk dikarenakan adanya pembelian yang berisiko dan penggunaannya merefleksikan atau mempengaruhi diri, pengembangan dari sebuah profil keterlibatan yang meliputi lima komponen, yaitu :

1) Ketertarikan pribadi yang dimiliki konsumen terhadap kategori produk, arti, dan kepentingan pribadi.

2) Kepentingan yang dipersepsi dari konsekuensi negatif yang potensial, diasosiasikan dengan pilihan produk yang menyedihkan.

3) Kemungkinan melakukan pembelian yang buruk.

4) Nilai tambahan dari kategori produk.

5) Nilai tanda dari kategori produk (berhubungan dengan diri).

Riset ini dilakukan dengan menanyakan suatu perangkat dari kategori produk yang mencerminkan setiap sisi dari keterlibatan. Variasi tingkat keterlibatan konsumen menghasilkan proses aktivasi kognisi yang sangat berbeda, ketika sebuah pesan diterima. Riset membuktikan bahwa tingkat keterlibatan menentukan aspek komunikasi mana yang diproses.

\section{Dimensi Impact}

Dimensi Impact menunjukkan, apakah suatu merek dapat terlihat menonjol dibandingkan merek lain pada kategori yang serupa dan apakah suatu iklan mampu melibatkan konsumen dalam pesan yang di sampaikan. Dampak (impact) yang diinginkan dari hasil iklan adalah jumlah pengetahuan produk (product knowledge) yang dicapai konsumen melalui tingkat keterlibatan (involvement) konsumen dengan produk dan atau proses pemilihan. Konsumen memiliki tingkat pengetahuan produk (levels of product knowledge) yang berbeda-beda, yang dapat digunakan untuk menerjemahkan informasi baru dan membuat pilihan konsumen. 
Konsumen dapat memiliki empat tingkat pengetahuan produk, yaitu : kelas produk, bentuk produk, merek, dan model.

\section{Dimensi Komunikasi}

Dimensi komunikasi memberikan informasi tentang kemampuan konsumen dalam mengingat pesan utama yang disampaikan, pemahaman konsumen, serta kekuatan kesan yang ditinggalkan pesan tersebut. Perspektif pemrosesan kognitif adalah inti untuk mengembangkan strategi pemasaran yang berhasil yang merupakan permasalahan komunikasi. Proses dimulai ketika sumber komunikasi promosi menentukan informasi apa yang harus dikomunikasikan, kemudian meng-enkoding pesan tersebut dalam bentuk simbol-simbol yang paling tepat (menggunakan kata, gambar, atau tindakan).

\section{Kerangka Konseptual}

Iklan merupakan salah satu intrumen pemasaran modern yang aktivitasnya didasarkan pada konsep komunikasi. Berhasil melaksanakan promosi dengan efektif dan efisien merupakan keberhasilan program pemasaran perusahaan. Bagi perusahaan yang akan mengiklankan produknya melalui media elektronik menjadi alternatif pilihan yang menarik, disamping jangkauannya luas, juga adanya unsur hiburan sangat mendukung pembentukan persepsi konsumen terhadap suatu merek dan akhirnya iklan menjadi efektif.

Iklan adalah salah satu komponen marketing mix yang umum dilakukan oleh perusahaan, kegiatan iklan dianggap sangat penting jika ingin produknya sukses di pasar. Setiap tahun, bahkan setiap launching produk baru, perusahaan menghabiskan ratusan juta bahkan miliaran rupiah untuk pengeluaran biaya iklan. Kondisi persaingan yang semakin ketat membuat biaya ini bertambah setiap tahunnya. Perusahaan berlomba-lomba membuat iklan untuk menarik konsumen membeli produknya. Iklan adalah segala bentuk presentasi nonpribadi dan promosi gagasan, barang atau jasa oleh sponsor tertentu yang harus dibayar (Kotler dan Keller, 2009:244).

Pengukuran efektivitas iklan sangat penting dilakukan, agar dapat diketahui pencapaian tujuan program dan kegiatan promosi perusahaan. Efektivitas sangat bergantung pada pemilihan media yang sesuai dengan strategi pemasaran perusahaan. Indikator keberhasilannya adalah tercapainya pasar sasaran yang ingin dijangkau, merek perusahaan menjadi dikenal baik oleh konsumen dan memiliki dampak terhadap peningkatan penjualan perusahaan.

Kemudahan pemahaman merupakan indikator yang penting dalam efektivitas pesan. Efektivitas suatu iklan bergantung pada apakah konsumen mengingat pesan yang disampaikan, memahami pesan tersebut, terpengaruh oleh pesan dan tentu saja pada akhirnya membeli produk yang diiklankan. Efektivitas iklan juga dapat diukur dengan menggunakan EPIC model oleh AC Nielsen. EPIC Model mencakup empat dimensi kritis yaitu empati (empathy), persuasi (persuasion), dampak (impact) dan komunikasi (communications).

Berdasarkan tentang teori dan tujuan yang ingin dicapai dalam penelitian ini, maka dapat digambarkan dalam kerangka konseptual yang akan menjadi acuan dalam penelitian ini. Indikator-indikator efektivitas iklan dipengaruhi oleh perilaku konsumen dalam penelitian ini dikembangkan dari sosial, pribadi, dan 
psikologis, serta bagaimana tindakan-tindakan keputusan konsumen terhadap produk tersebut.

Ada beberapa kriteria pengukuran iklan yaitu dengan melihat hasil penjualan, pengingatan dan persuasi. Dalam hal ini pengukuran efektifitas iklan produk sirup Pohon Pinang dengan melihat nilai rata-rata iklan dari empat dimensi (Empathy, Persuasion, Impact, dan Communication). Faktor efektivitas iklan dengan EPIC-Model produk yang beredar di pasaran dapat mempengaruhi penjualan. Sebagaimana dapat digambarkan berikut ini :

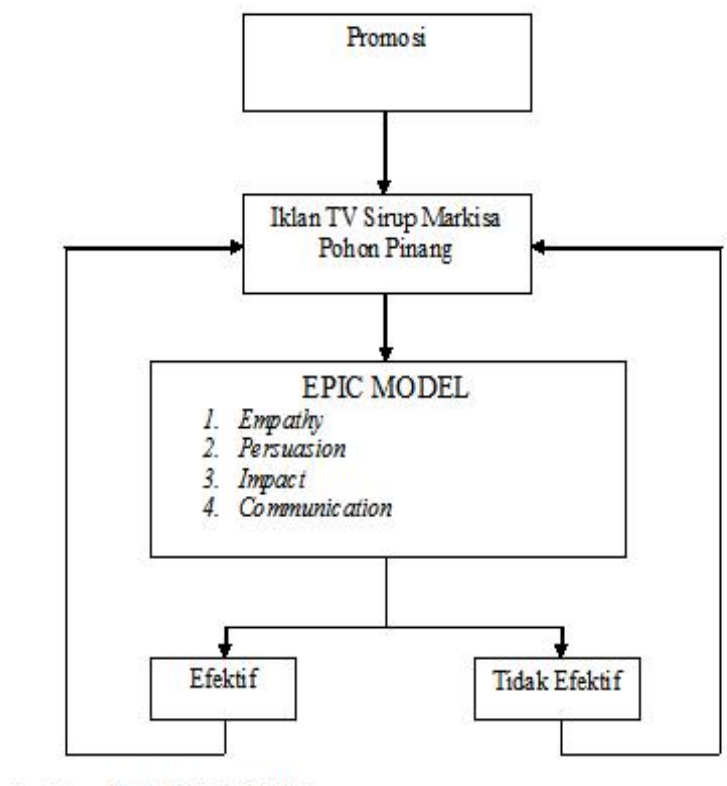

Sumber : Data Diolah, (2012)

Gambar 2.1 Kerangka Konseptual

\section{Hipotesis Penelitian}

Berdasarkan kerangka konseptual diatas, maka dapat diperoleh hipotesis sebagai berikut : 1) Iklan televisi sirup markisa secara keseluruhan dilihat dari empat dimensi EPIC-Model (Empathy, Persuasion, Impact, dan Communication) sangat efektif. 2) Iklan televisi sirup markisa secara parsial dilihat dari masingmasing dimensi EPIC MODEL sangat efektif.

\section{METODE}

Pendekatan jenis penelitian yang digunakan dalam penelitian ini adalah menggunakan statistik deskriptif dan sifat penelitian adalah explanatory, yaitu suatu penelitian yang bermaksud menjelaskan kedudukan variabel-variabel yang diteliti serta hubungan antara satu variabel dengan variabel yang lain. Dalam penelitian ini yang menjadi sasaran penelitian adalah konsumen yang pernah membeli sirup Pohon Pinang dan datang berbelanja di Swalayan Macan Yaohan Merak Jingga Medan selama bulan Mei - Juli 2012. 
Untuk memperoleh $\mathrm{n}$ (jumlah sampel), maka dapat digunakan $\alpha=0,05$. Dengan demikian jumlah sampel yang mewakili populasi dalam penelitian ini adalah :

$$
\begin{array}{ll}
\mathrm{n} & =\frac{\left(Z_{\alpha / 2} \sigma\right)^{2}}{(e)^{2}} \\
\mathrm{n} \quad & =\frac{(1,96)^{2} \cdot(0,25)^{2}}{(0,05)^{2}} \\
\mathrm{n} \quad & =96,04 \sim 100 \text { orang. }
\end{array}
$$

Teknik pengambilan sampel menggunakan metode Accidental sampling adalah teknik penentuan sampel yang penentuan sampel berdasarkan kebetulan, yaitu siapa saja yang secara kebetulan ditemui sedang berada ditempat (Swalayan Macan Yaohan Merak Jingga) dapat terpilih untuk dijadikan responden.

Teknik pengumpulan data pada penelitian ini adalah : kuesioner dan Studi pustaka. Jenis data yang diperoleh dikelompokkan menjadi dua : 1) Data primer adalah data yang langsung diperoleh dari obyeknya. Pada penelitian ini data primer diperoleh dari hasil survey dan pengisian kuesioner untuk mengetahui efektivitas iklan sirup markisa Pohon Pinang dengan EPIC-Model di Medan. 2) Data sekunder merupakan sumber data penelitian yang diperoleh peneliti secara tidak langsung melalui media perantara (diperoleh dan dicatat oleh pihak lain).

\section{Uji Validitas dan Uji Reliabilitas}

Berikut ini hasil uji validitas dan uji reliabilitas instrumen pertanyaan dari variabel yang sudah ditentukan antara lain :

Tabel 3.3

Hasil Uji Validit as Instrumen Pertanyaan Empathy (XI)

\begin{tabular}{llccc}
\hline No & \multicolumn{1}{c}{ Indikator } & $\begin{array}{c}\text { Nilair } \\
\text { hitung }\end{array}$ & $\begin{array}{c}\text { Nilai r } \\
\text { tabel }\end{array}$ & Keterangan \\
\hline $1 \quad$ & $\begin{array}{l}\text { Iklan sirup Markisa PohonPinang } \\
\text { versi iklannya "Ahlinya Marquisa }\end{array}$ & 0,797 & 0,30 & Valid \\
$\begin{array}{l}\text { Juice" merupakan iklan yang mudah } \\
\text { dimengerti }\end{array}$ & & & \\
$2 \quad \begin{array}{l}\text { Iklan sirup Markisa PohonPinang } \\
\text { versi iklannya "Ahlinya Marquisa } \\
\text { Jucie" merupakan iklan yang mampu } \\
\text { membuat saya merasakan nikmatnya } \\
\text { sirup markisa }\end{array}$ & & 0,790 & Valid \\
Sumber : Data Diolah, (2012) & & &
\end{tabular}


Tabel 3.4

Hasil Uji Valid itas Instrumen Pertanyaan Persuasion (X2)

\begin{tabular}{lllcc}
\hline No & \multicolumn{1}{c}{ Indikator } & $\begin{array}{c}\text { Nilair } \\
\text { hitung }\end{array}$ & $\begin{array}{c}\text { Nilai r } \\
\text { tabel }\end{array}$ & Keterangan \\
$1 \quad \begin{array}{l}\text { Kata-kata dalam Iklan sirup Markisa } \\
\text { PohonPinang pada berbagai media } \\
\text { menarik perhatian saya }\end{array}$ & 0,870 & 0,30 & Valid \\
$2 \quad \begin{array}{l}\text { Tampilan iklan sirup Markisa } \\
\text { PohonPinang pada berbagai media iklan } \\
\text { menarik perhatian Saya }\end{array}$ & 0,889 & 0,30 & Valid \\
\hline Sumber : Data Diolah, (2012) & & & \\
\hline
\end{tabular}

Tabel 3.5

Hasil Uji Validitas Instrumen Perta nyaan Impact (X3)

\begin{tabular}{|c|c|c|c|c|}
\hline No & Indikator & $\begin{array}{l}\text { Nilair } \\
\text { hitung }\end{array}$ & $\begin{array}{c}\text { Nilai r } \\
\text { tabel }\end{array}$ & Keter angan \\
\hline \multirow[t]{2}{*}{$\overline{1}$} & $\begin{array}{lll}\text { Saya } & \text { percaya terhadap informasi }\end{array}$ & & & \\
\hline & $\begin{array}{l}\text { produk yang terdapat dalam iklan sirup } \\
\text { markisa PohonPinang }\end{array}$ & 0,782 & 0,30 & Valid \\
\hline 2 & $\begin{array}{l}\text { Saya bersedia memilih dan membeli } \\
\text { sirup markisa PohonPinang karena } \\
\text { memiliki keunggulan dan merupakan } \\
\text { ahlinya Markisa Juice }\end{array}$ & 0,752 & 0,30 & Valid \\
\hline
\end{tabular}

Sumber : Data Diolah, (2012)

Tabel 3.6

Hasil Uji Validitas I nstrumen Pertanya an Communic ation (X4)

\begin{tabular}{|c|c|c|c|c|}
\hline No & Indikator & $\begin{array}{l}\text { Nilair } \\
\text { hitung }\end{array}$ & $\begin{array}{c}\text { Nilai r } \\
\text { tabel }\end{array}$ & Keter angan \\
\hline$\overline{1}$ & $\begin{array}{l}\text { Menurut saya informasi iklan sirup } \\
\text { markisa PohonPinang lebih jelas } \\
\text { dibandingkan dengan iklan lainnya }\end{array}$ & 0,877 & 0,30 & Valid \\
\hline 2 & $\begin{array}{l}\text { Tklan sirup markisa PohonPinang } \\
\text { memberikan informasi yang saya } \\
\text { butuhkan }\end{array}$ & 0,889 & 0,30 & Valid \\
\hline 3 & $\begin{array}{l}\text { Menurut saya slogan "Ahlinya } \\
\text { Marquisa Juice" dan iklan sirup } \\
\text { markisa PohonPinang mencerminkan } \\
\text { kenikmatan dalam mengkonsumsinya }\end{array}$ & 0,693 & 0,30 & Valid \\
\hline & er : Data Diolah, (2012) & & & \\
\hline
\end{tabular}


Data yang diperoleh dianalisis dengan menggunakan analisis statistik (univariat) dan analisis tabulasi sederhana dan skor rata-rata. Menurut Durianto, dkk (2003) dalam analisis tabulasi sederhana, data yang diperoleh kebentuk presentase, dengan rumus sebagai berikut:

$$
\mathrm{P}=\frac{F i}{\bar{F} i} x 100 \%
$$

Dimana :

$$
\begin{array}{ll}
\mathrm{P} & : \text { Persentase responden yang memilih kategori tertentu } \\
\mathrm{Fi} & : \text { Jumlah persentase responden yang memilih kategori tertentu } \\
\sum \mathrm{Fi} & : \text { Jumlah responden }
\end{array}
$$

Setiap jawaban responden dari pertanyaan yang diberikan, diberikan bobot. Cara menghitung skor adalah dengan menjumlahkan seluruh hasil kali, nilai masing-masing bobotnya dibagi dengan jumlah total frekuensi.

$$
\frac{\Sigma F t \cdot W i}{\Sigma F t}
$$

Dimana :

$\begin{array}{ll}X & : \text { rata-rata Bobot } \\ \mathrm{Fi} & : \text { Frekuensi } \\ \mathrm{W} & : \text { Bobot }\end{array}$

Setelah itu, digunakan skala penilaian untuk menentukan posisi tanggapan responden dengan menggunakan nilai skor. Setiap variabel bobot alternatif jawaban yang terbentuk dari teknik skala Likert peringkat terdiri dari kisaran antara 1 sampai 5. Selanjutnya dihitung rentang skala dengan rumus, sebagai berikut:

Dimana :

$$
\mathrm{Rs}=\frac{R(b o b o t)}{M}
$$

R (bobot) : bobot terbesar - bobot terkecil

$\mathrm{M} \quad$ : banyaknya kategori bobot

Setiap dimensi EPIC Model yaitu empathy (empati), persuasion (persuasi), impact (dampak), communication (komunikasi), akan dianalisis secara terpisah dengan menggunakan metode skor rata-rata untuk mengetahui efektifitas tiap dimensi tersebut dalam iklan televisi produk sirup markisa yang nantinya nilai ratarata itu akan dimasukkan dalam rentang skala posisi keputusan digunakan.

\section{PEMBAHASAN}

\section{Hasil Deskriptif Responden (Univariat)}

Adapun analisis yang dilakukan ini hanya menghasilkan distribusi dan persentase yang meliputi usia, jenis kelamin, pengeluaran per bulan, jenis pekerjaan, dan sumber informasi iklan sirup markisa PohonPinang dari tanggapan responden. 
Berdasarkan usia responden menunjukkan bahwa mayoritas responden sebesar $45 \%$ berusia antara 36-45 tahun, 33\% berusia antara 26-35 tahun, 13\% berusia $\geq 50$ tahun dan 9\% berusia 17-25 tahun. Hal ini menunjukkan bahwa sampel yang ditemui didominasi merupakan usia produktif dan aktif dalam aktivitasnya dalam ini memiliki mobilitas tinggi, sehingga usia responden diatas dapat dikatakan responden yang sudah berpengalaman.

Berdasarkan jenis kelamin responden menunjukkan bahwa mayoritas responden sebesar 53\% berjenis kelamin perempuan dan sisanya $47 \%$ berjenis kelamin laki-laki. Hal ini menunjukkan bahwa sampel yang ditemui adalah perempuan alasannya karena pada dasarnya perempuan yang berbelanja untuk kebutuhan sehari-hari. Selain untuk tujuan berbelanja bagi mereka (perempuan) sebagai sarana rekreasi, dan wanita memang suka belanja, tidak menutup kemungkinan bagi laki-laki juga senang berbelanja, tetapi pada dasarnya laki-laki sebagaian besar waktunya dihabiskan untuk bekerja.

Berdasarkan pengeluaran per bulan responden menunjukkan bahwa mayoritas 35\% pengeluaran responden rata-rata per bulan Rp. 1.000 .000 , 31\% pengeluaran rata-rata per bulan Rp. $1.500 .000,22 \%$ pengeluaran rata-rata per bulan Rp. 2.000.000 dan 12\% pengeluaran diatas Rp 2.500.000. Jumlah ini menunjukkan bahwa pengeluaran per bulan pengunjung Swalayan Macan Yaohan Merak Jingga yang ditemui peneliti relatif memiliki tingkat pendapatan cukup besar.

Berdasarkan jenis pekerjaan responden menunjukkan bahwa responden yang dalam penelitian ini $37 \%$ bekerja sebagai pegawai swasta, $26 \%$ bekerja sebagai wiraswasta, $19 \%$ bekerja sebagai pegawai negeri sipil dan $10 \%$ bekerja sebagai mahasiswa serta $8 \%$ bekerja sebagai profesional. Sehingga mayoritas konsumen yang datang ke Swalayan Macan Yaohan Merak Jingga yaitu pegawai swasta, hal ini dikarenakan beberapa pengunjung perempuan yang berprofesi ganda baik sebagai pekerja juga sebagai ibu rumah tangga yang memiliki kepentingan untuk memenuhi kebutuhan rumah tangga.

Berdasarkan sumber informasi responden menunjukkan bahwa responden dalam penelitian ini 56\% memperoleh sumber informasi iklan sirup markisa PohonPinang dari televisi, $13 \%$ dari word of mouth, 12\% dari koran, $10 \%$ dari Spanduk/baliho/billboard, 6\% dari brosur dan 3\% radio. Mayoritas responden mendapatkan informasi tentang iklan sirup Markisa PohonPinang adalah televisi. Hal ini menunjukkan bahwa televisi menjadi sumber informasi utama dan paling efektif bagi responden untuk mendapatkan informasi produk, secara keseluruhan media informasi yang berbentuk iklan melalui media elektronik dan media cetak merupakan alat komunikasi yang dapat menyampaikan produk perusahaan.

\section{Hasil Analisis Statistik}

Penilaian pertanyaan-pertanyaan EPIC model menggunakan skala Likert dengan rentang skala yang digunakan adalah antara satu sampai lima dan diberi bobot. Berikut adalah rentang skala berdasa:kan bobot skor penilaian yang diperoleh dalam kuesioner.

$0,8+1,0=1,8$ (Sangat Tidak Setuju)

$$
\mathrm{Rs}=\frac{5-1}{5}==0,8
$$

$0,8+1,8=2,6$ (Tidak Setuju)

$0,8+2,6=3,4$ (Kurang Setuju) 
$0,8+2,6=4,2$ (Setuju)

$0,8+4,2=5,8$ (Sangat Tidak Setuju)

Sehingga diperoleh posisi keputusan seperti terlihat dalam Gambar 4.5 berikut :

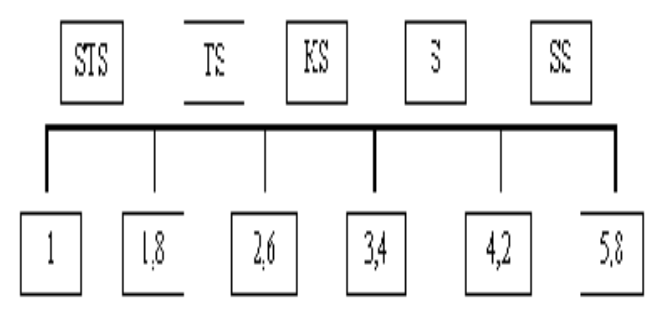

\section{1). Dimensi Emphaty (X1)}

Nilai rata-rata dari dimensi empathy $(\mathrm{X} 1)=\frac{(4,08)+(4,1)}{2}=4,09$

\section{2) Dimensi Persuasion (X2)}

Nilai rata-rata dari dimensi persuasion $(\mathrm{X} 2)=\frac{(4,19)+(4,03)}{2}=4,11$

\section{3) Dimensi Impact (X3)}

Nilai rata-rata dari dimensi impact $(\mathrm{X} 3)=\frac{(3,90)+(4,05)}{2}=3,98$

\section{4) Dimensi Communication (X4)}

Nilai rata-rata dari dimensi Communication (X4)

$$
=\frac{(3,89)+(3,74)+(4,15)}{3}=3,92
$$

Secara keseluruhan dari hasil analisis efektivitas iklan sirup markisa Pohon Pinang dengan menggunakan EPIC - Model pada konsumen yang berkunjung pada swalayan Macan Yaohan Merak Jingga Medan dapat digambarkan dalam grafik kuadran sebagai berikut: 


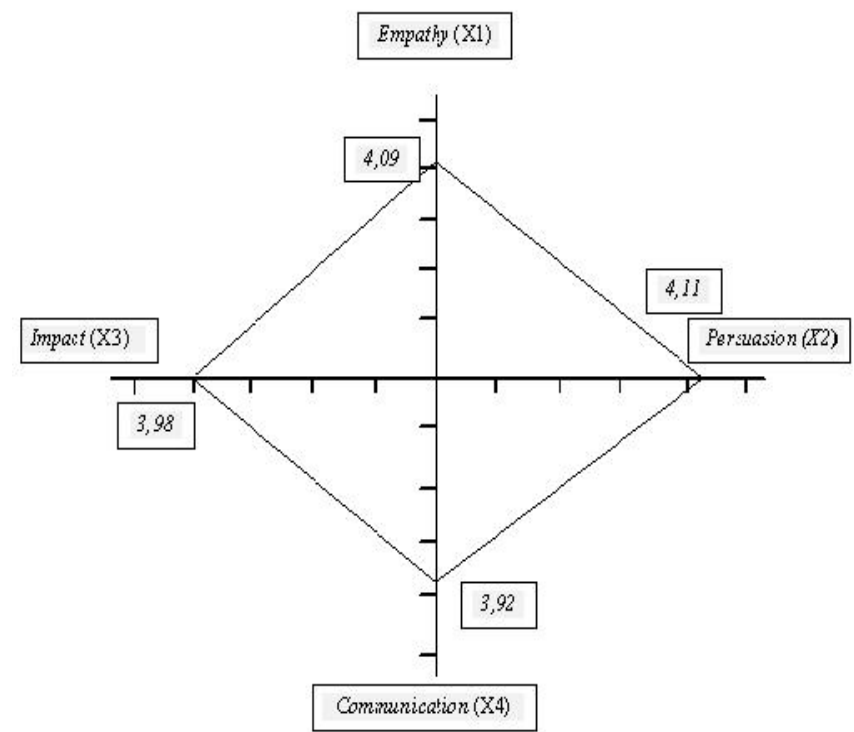

Berdasarkan Gambar 4.7 diatas, menunjukkan hasil iklan sirup markisa Pohon Pinang ditelevisi adalah efektif, iklan yang efektif yaitu iklan yang mampu membuat konsumen tertarik untuk mengkonsumsi produk sirup markisa Pohon Pinang, mampu menyampaikan pesan, baik informasi keunggulan maupun perbedaan produk dibandingkan dengan produk sejenis lainnya.

Efektivitas iklan sirup markisa Pohon Pinang dapat dilihat dari keempat kategori EPIC model untuk iklan sirup markisa Pohon Pinang, yaitu 4,09 untuk dimensi empathy, 4,11 untuk dimensi persuasion, 3,98 untuk dimensi impact dan 3,92 untuk dimensi communication.

\section{KESIMPULAN}

Kesimpulan

Kesimpulan analisis efektivitas iklan dengan menggunakan EPIC Model yang terdiri dari dimensi Empathy, Persuasion, Impact dan Communication adalah sebagai berikut :

1. Dimensi Empathy

Pada dimensi ini terdapat dua item pertanyaan dan memiliki skor kumulatif 4,09 masuk dalam kategori setuju, artinya dari hasil penelitian terhadap dimensi empati menggambarkan konsumen mampu memahami dan ikut merasakan nikmatnya sirup markisa Pohon Pinang.

2. Dimensi Persuasion

Pada dimensi ini terdapat dua item pertanyaan dan memiliki skor kumulatif 4,11 masuk dalam kategori setuju, artinya tampilan dan kata-kata dalam iklan sirup markisa Pohon Pinang mampu menarik perhatian konsumen.

3. Dimensi Impact

Pada dimensi ini terdapat dua item pertanyaan dan memiliki skor kumulatif 3,98, masuk dalam kategori setuju, artinya dampak yang dapat diperoleh dari 
iklan tersebut adalah konsumen mendapatkan pengetahuan dari iklan prouk sirup markisa PohonPinang.

4. Dimensi Communication

Pada dimensi ini terdapat tiga item pertanyaan dan memiliki skor kumulatif 3,92 masuk dalam kategori setuju, hal ini menunjukkan bahwa dimensi komunikasi memberikan informasi tentang kemampuan konsumen dalam mengingat pesan utama yang disampaikan dan pemahaman konsumen terhadap pesan yang disampaikan sangat baik.

5. Dari keempat analisa dimensi EPIC dapat disimpulkan bahwa dimensi Persuasion mendapatkan skor tertinggi sebesar 4,11. Hal ini membuktikan bahwa iklan sirup markisa PohonPinang berhasil mempengaruhi keyakinan konsumen untuk menyukai sirup markisa Pohon Pinang.

\section{Saran}

Berdasarkan hasil dari penelitian yang telah dilakukan, maka saran yang dapat dijadikan bahan pertimbangan adalah sebagai berikut :

1. Mengingat image yang telah dibangun oleh iklan sirup markisa Pohon Pinang selama ini, sebaiknya terus mempertahankan iklan yang sudah baik dan terus berkreasi dalam menciptakan iklan yang kreatif.

2. Sebaiknya perusahaan terus berinovasi dalam hal kualitas produknya, agar konsumen tidak hanya sekedar menjadi penikmat tayangan iklan, tetapi juga memperoleh dan merasakan manfaat produk secara nyata.

3. Perusahaan sebaiknya mulai mempertimbangkan untuk membuat iklan yang berbeda untuk masing-masing kategori produk, mempertimbangkan komunikasi masing-masing produk bisa berbeda sesuai dengan keunggulannya.

4. Perusahaan disarankan untuk megidentifikasi keunggulan bersaing secara berkala, untuk mengetahui tema iklan yang unggul untuk memenangkan persaingan yang semakin kompetitif.

5. Untuk penelitian selanjutnya, perlu dilakukan pengembangan penelitian lebih lanjut mengenai analisis kegiatan promosi dengan menggunakan alat analisis yang berbeda, misalnya dengan menggunakan analisis regresi linear berganda dan struktural equation model untuk mengetahui dampak iklan yang lebih luas lagi.

\section{DAFTAR PUSTAKA}

Akhdon. 2011. Cara Menggunakan dan Memaknai Path Analysis (Analisis Jalur). Bandung. Alfabeta.

Assauri, Sofyan. 2004. Manajemen Pemasaran. Jakarta. PT. Raja Grafindo Persada.

Arikunto, Suharsimi. 2006. Prosedur Penelitian Suatu Pendekatan Praktik. Jakarta.. Rhineka Cipta. 
Belch, George. 2004. Advertising and Promotion: An Integrated Marketing Communications Perspective. 7th Edition. McGraw-Hill.

Bram, Yudi Farola. 2005. Analisis Efektivitas Iklan Sebagai Salah Satu Strategi Pemasaran Perusahaan Percetakan dan Penerbitan PT Rambang Dengan Menggunakan Metode EPIC Model. Tesis. Universitas Sriwijaya. Magister Manajemen.

Durianto, Darmandi, dkk. 2003. Invasi Pasar dengan iklan yang Efektif. Jakarta. PT. Gramedia Pustaka Utama.

Efendy, Heru. 2002. Mari Membuat Film: Panduan Menjadi Produsen. Jakarta. Yayasan Konfiden.

Firdaus Aulia, Rika. 2009. Pengukuran Efektifitas Iklan Televisi Sepeda Motor Yamaha Versi Lagu Group Band Dewa "Yamaha Semakin Didepan. Dengan Pendekatan EPIC Model (Pada Dealer Sepeda Motor Yamaha Timbul Jaya Blitar). Skripsi. Fakultas Ekonomi Universitas Islam Negeri (UIN) Malang.

Ginting, Paham. 2011. Pemasaran Pariwisata : Studi Empiris Tentang Kepuasan dan Kunjungan Berkelanjutan Pariwisata Sumatera Utara. Medan. Usu Press.

Hasan, Ali. 2008. Marketing. Yogyakarta. Media Utama.

Kotler, Philip. 2003. Marketing Management. International Edition. New Jersey. Prentice Hall.

Kotler, Philip dan Gary, Amstrong. 2003. Dasar-Dasar Pemasaran. Edisi Kesembilan.Jilid 1. Jakarta. PT. Indeks. . 2004. Dasar-Dasar Pemasaran. Edisi Kesembilan. Jilid 2. Jakarta. PT. Indeks.

Kotler, Philip dan Keller K Lane. 2009. Manajemen Pemasaran. Edisi Ketiga Belas. Jilid 1. Penerbit Erlangga : Jakarta. PT. Gelora Aksara Pratama.

. 2009. Manajemen Pemasaran. Edisi Ketiga Belas. Jilid 2. Penerbit Erlangga: Jakarta. PT. Gelora Aksara Pratama.

Kasali, Rhenald. 2007. Manajemen Periklanan Konsep dan Aplikasinya di Indonesia. Cetakan V: Jakarta. Pustaka Utama Grafiti.

Schiffman, Leon, dan Kanuk, Leslie Lazar. 2010. Consumer Behaviour 7th Edition (Perilaku Konsumen). Jakarta. PT. Indeks Kelompok Gramedia. 
Sian Yet. 2011. Star Marketing for Everyone's Business. Jakarta. PT. Gramedia Pustaka Utama.

Sugiyono. 2010. Metode Penelitian Kuantitatif Kualitatif dan $R \& D$. Penerbit Bandung. ALFABETA.

Sutisna. 2003. Perilaku Konsumen dan Komunikasi Perusahaan. Bandung. PT. Remaja Rosdakarya.

Tjiptono, Fandy. 2002. Strategi Pemasaran. Yogyakarta. Cetakan Keenam. Penerbit Bandung. Andi.

Umar, Husein. 2005. Metode Penelitian. Jakarta. Salemba Empat.

Wells, Burnett dan Moriaty. 2003. Advertising Principles and Practice. 5th Edition. Prentice Hall.

Wiyono, Arsi. 2008. Analisis Efektivitas Iklan Televisi Sampoerna Hijau Versi "Teman Bisa Jadi Pegangan" (Studi Pada Penduduk Desa Jeruk Seger Kecamatan Gedeg Kabupaten Mojokerto). Skripsi. Universitas Muhammadiyah Malang. Jawa Timur. 